DRAFT - Please do not circulate without the author's permission

\title{
Historical Agency and the Coloniality of Power in Postsocialist Europe
}

Dace Dzenovska, COMPAS, University of Oxford

\begin{abstract}
In this article, I analyse the ways in which coloniality as a racialized and racializing rationality of government and knowledge production shapes political and historical subjects in postsocialist Europe. I analyse Latvian attempts to establish historical presence in European modernity through appropriation of $17^{\text {th }}$ century colonial pursuits of the Duchy of Courland into Latvian national history, as well as interpretations of this historical appropriation by Western scholars and travellers. I argue that Latvian identification with Europe's colonial past not only renders visible the continued salience of coloniality in European politics, but also illuminates the mechanisms through which Europe attempts to renew its moral superiority in the global arena by relegating colonialism to a past that Europe claims to have overcome and that Latvians are required to overcome to become fully European. I argue that in order to understand how coloniality continues to inform political life in contemporary Europe it is necessary to move beyond analysis of national histories and deploy a relational approach which traces how contemporary political subjects are constituted in racialized and racializing fields of power relations. It is also necessary to analyse postsocialist Eastern Europe not only in relation to the socialist past, but also the global present.
\end{abstract}

\section{Keywords:}

Historical agency, nationalism, postsocialism, coloniality of power, Europe 
DRAFT - Please do not circulate without the author's permission

\section{The Encounter}

In a Baltic Times article entitled “Tobacco? No, Tobago!” Portuguese journalist Joao Lopes Marques describes how Inese, a "proud local Latvian," tried to compensate the proliferation of media reports about the gravity of the recent financial crisis in Latvia by saying to him: "But did you know that we once had a colonial empire? Did you know that Tobago Island was ours?” (Lopes Marques, 2009). Inese dispelled Lopes Marques' initial disbelief by guiding him through historical materials and public spaces which attested to the connection many Latvians make between the current-day Latvian nation and the $17^{\text {th }}$ century colonial pursuits of the Duchy of Courland. The Duchy of Courland, a vassal state to the Grand Duchy of Lithuania and, subsequently, to the Polish-Lithuanian Commonwealth, existed in the territory of current-day Latvia between 1562 and 1726. The reign of the Baltic German Duke Jacob Kettler between 1642 and 1682 is commonly thought of as the golden time of the Duchy, a time when it prospered as a result of agricultural production, manufacture, and trade. Duke Jacob had purchased Tobago, along with a trading station on the River Gambia in West Africa, in order to participate in the Atlantic triangle trade - that is, bringing manufactured goods and iron to West Africa, exchanging them for slaves, shipping the slaves to the Caribbean or the Americas, and then returning to Europe with sugar and other goods (Andersons, 1970a; Merritt, 2010). As explained by historian Mārīte Jakovḷeva, the Duke wanted to "act on the global stage," for which being involved in colonial pursuits was central at the time. ${ }^{i}$ The Duke had these colonies between 1651 and 1658 when he lost them to the British.

The Duchy's glories, especially its naval fleet, remain legendary to this day (Zalsters, 2002). Contemporary Latvian writers, literary scholars, filmmakers, government institutions, and ordinary Latvians routinely invoke the link between the colonial pursuits of the Duchy 
DRAFT - Please do not circulate without the author's permission

and Latvian national history. The website of the Latvian Institute-an institution charged with disseminating information about Latvia to an international audience-describes the Courland fleet and its colonial pursuits as noteworthy elements of Latvian history. In 2001, renowned Latvian poet Māra Zālīte wrote a musical entitled “Tobago!” where she depicts the travails of Courlanders, including Latvians, in Tobago. References to the Duchy in public life tend to intensify around commemorative events, such as the Duke's 400th birthday in 2010, which involved a range of celebratory events across Latvia, the publication of books (e.g. Mirbahs, 2010), as well as television shows on the relevance of the history of the Duchy for contemporary Latvians. The glories of Duke Jacob are also sedimented in popular consciousness insofar as people routinely invoke the Duchy's colonial history in situations where they feel compelled to boost Latvia's historical credentials.

What is noteworthy about the encounter between Inese, a "proud local Latvian," and Joao Lopes Marques, a Portuguese journalist, is not only the Latvians' colonial aspirations, but also the reaction of Lopes Marques who himself hails from a former imperial power with more than its share of nostalgia for the glories of the imperial past (Arenas, 2006). Lopes Marques interprets the Latvians' colonial aspirations as an instance of "Baltic minimegalomania" which he interchangeably attributes to the Latvian "genetic code" and "the admirable effort to transcend smallness." Harry C. Merritt, a self-described "writer and nonprofit professional" and a former intern of the U.S. State Department at the U.S. Embassy in Riga, who also encountered references to Tobago in Latvian public life, offers a more scholarly interpretation. In an article published in Nationalities Papers, Merritt introduces the problem from the perspective of a "Western European and North American traveller" who, Merritt writes, may be "bemused" and "baffled" when encountering references to Tobago in public space, as well as scholarly and political discourse in Latvia (Merritt, 2010: 491). While Merritt also seeks to identify maladies that can account for the Latvians' colonial aspirations, 
DRAFT - Please do not circulate without the author's permission

he is more explicit about the perspective from which the Latvians' colonial aspirations demand an explanation, that is, the perspective of the Western European and North American traveller. Moreover, he begins by affectively interpellating the reader as a fellow Western traveller or scholar who also may be baffled and bemused and only subsequently articulates an explanation of the Latvians' colonial aspirations with the help of Western social theory, namely Anthony D. Smith's “ethno-symbolist theory” (Merritt, 2010). ${ }^{\text {ii }}$

In this article, I diverge from Merritt and Lopes Marques insofar as I do not posit the Latvians' colonial aspirations as a bounded phenomenon that can be explained by comparing it with others like it. Rather, I am interested in how the problem shifts when one examines the encounter between Latvians with colonial aspirations and Western European and North American travellers who attempt to explain them, that is, when one shifts focus from Latvians as objects of inquiry to the relational dynamic that constitutes both Latvians as objects of inquiry and the Western European and North American traveller as the knowing and interpreting subject. In other words, the problem that this article engages is not how the Soviet past shapes the Latvians' colonial aspirations. Rather, it pertains to how the historical myth of Latvia's colonial history and its interpretations are relationally constituted vis-à-vis the racializing and racialized power relations of coloniality, a term that Peruvian scholar Anibal Quijano has introduced to suggest that European modernity is constituted through colonial power relations and the associated epistemologies of racial hierarchies which emerged in the $16 \mathrm{~h}$ century with the establishment of the Atlantic trade circuit (Quijano, 2000; Mignolo \& Escobar 2009; Tlostanova, 2012; see also Rabinow, 1995; Mitchell, 1991; Stoler, 2002).

It is important to note that I do not suggest that describing the Latvians' colonial aspirations as part of a nationalist myth is wrong. Rather, I suggest that a mere diagnosis of nationalism hinders rather than aids analysis. Diagnosis of nationalism becomes a shorthand 
DRAFT - Please do not circulate without the author's permission

critique with little analytical traction. I suggest to add another dimension to the analysis, namely an investigation of how coloniality shapes the contemporary political topography in Europe where it has been crucial in maintaining a distinction between "good" and "bad" nationalisms, between "mature" and "less mature" political subjects. ${ }^{\text {iii }}$ These distinctions are racialized insofar as even if detached from visible markers of race, such as skin colour, they are embedded in the colonial and racial logic of global capitalism (Ferreira da Silva, 2005, Chakravarty \& Ferreira da Silva, 2012). Within this logic, to be deemed more or less mature politically also means to be placed on a racialized scale of human difference. Within this logic, as I will elaborate in this article, to aspire to colonial history also means to become racially marked vis-à-vis racialized colonial subjects.

The Latvians' colonial aspirations are particularly interesting, because they unfold at a time when Europe's colonial past has come to haunt the present — questions of immigration, citizenship and racism explode in public and political life on a daily basis. Under such conditions, turning to a colonial past in order to assert a positive global presence is controversial even as coloniality continues to structure public and political life in Europe. European liberals labour hard to separate European political and civilizational virtues from the European history of colonial expansion and slave trade, the latter always already threatening to expose Europe's political achievements as a ruse of domination, especially in conditions when the racialized dynamics of coloniality explicitly inform public addresses of European politicians (Buck-Morss, 2009; Mehta, 1999; Böröcz, 2006; Ticktin, Bachetta \& Marshall 2007). ${ }^{\text {iv }}$ What is striking is that despite such explicit presence of the racializing logic of coloniality, as well as numerous scholarly arguments about the mutually constitutive nature of colonial history and European modernity, European liberals still successfully proceed with legitimating Europe, and the West more generally, as bearers of democratic values and freedom. 
DRAFT - Please do not circulate without the author's permission

It becomes possible to analyse this dynamic from the perspective of postsocialist Eastern Europe when one shifts the analytical focus from the Latvians' colonial aspirations to the encounter between the Latvians' colonial aspirations and the Western scholars' and travellers' interpretation of them. It becomes possible to consider the conditions that produce bafflement and bemusement from the specifically Western European and North American perspective. Does bafflement arise when those who have "real" colonial history observe how people in the small country of Latvia recruit marginal colonial events in the past of another political entity — the Duchy of Courland — for their national present? Or does it arise because this historical appropriation occurs at a time when the colonial past is hardly a source of pride in European public and political life? After all, 17th century colonial expansion went hand in hand with the slave trade and thus the glories of the colonial past are inseparable from its injuries. In the hegemonic self-narrative of Western Europe and North America, colonialism is a thing of the past that has been surpassed by values of freedom, democracy, and human rights. Yet in Latvia the Western European and North American traveller encounters Sovietcum-European subjects who seem to misinterpret what the Europe of today is about and seek to identify with its colonial history as much, if not more, than with the contemporary values of freedom, democracy, and human rights.

In Merritt's view, this is an indication that Latvian public and political life is overwhelmingly shaped by the Latvians' own recent colonial past at the hands of the Soviet state. Merritt suggests that Soviet domination, which he takes to be a form of colonialism, has diminished the Latvians' self-confidence and that the historical appropriation of the Duchy's colonial past compensates for this loss in the contemporary project of constructing a postsocialist national identity $(2010: 491,501)$. In offering this interpretation, Merritt, not unlike Lopes Marques, assumes a position of authority, which is located outside the historical 
DRAFT - Please do not circulate without the author's permission

terrain within which the historical appropriation takes place and which enables him to interpret the misguided identifications of Latvians.

By way of such a move, postsocialist Eastern Europe is recruited to assist in the project of asserting Western Europe's moral superiority. Post-Soviet Latvia is constituted as an almost-but-not-quite-European other who can achieve full membership in Europe through embracing (neo)liberal democracy with the help of the more mature European nation-states. It lends renewed legitimacy to the racialized developmentalist project in conditions when it has been subjected to critique in postcolonial theory and politics. It could be said that postsocialist Eastern Europe emerges as a kind of "spatial fix" through which Europe's internal tensions brought into focus by postcolonial critique can be temporarily deferred. However, as I will show in this article, the postsocialist objects of Europeanization unsettle this project of deferral insofar as they not only take up the discourses of free markets, human rights, and democracy as proof of Europe's civilizational superiority, but also strive to embrace the colonial underside of European modernity, thus undermining attempts at keeping the two separate.

To summarize, I take the encounter between the Latvians' colonial aspirations and Western explanations of them as good to think with about the coloniality of power in contemporary Europe. ${ }^{\mathrm{v}}$ In the following sections, I elaborate on coloniality as a racialized and racializing rationality of government and knowledge production, as well as an analytical framework that enables me to trace how Latvians and their observers are constituted as political and historical subjects in the global present. In doing so, I move beyond some of the impasses of debates about the relationship between postsocialism and postcolonialism to which I now turn. 
DRAFT - Please do not circulate without the author's permission

\section{The Coloniality of Power}

Merritt's deployment of the language of postcolonialism in relation to the Latvians' colonial aspirations gestures towards a growing body of scholarship that poses questions about the relationship between postcolonialism and postsocialism. Over the last two decades, it has become increasingly popular to consider whether postsocialism could benefit from a postcolonial perspective and vice versa. Early scholarship in this vein posed questions about the similarities and differences between the Soviet state and the British and French colonial empires, as well as the effects of the Soviet and colonial pasts on the post-Soviet and postcolonial presents (e.g. Northrop, 2004; Collier, et. al., 2003; Kelertas, 2006; Račevskis, 2002; Edgar, 2005; Chernetsky, 2003; Hirsch, 2005; Khalid, 2007). For example, some scholars have deployed postcolonial analytical tools to make sense of Soviet administrative practices in peripheral territories (e.g. Northrop 2004), while others have claimed postcolonial status for post-Soviet nations in order to obtain political recognition for the historical injury inflicted upon them by the Soviet regime (e.g. Kelertas 2006). Anthropologist Alexei Yurchak has urged against such hasty equation of the Soviet state with colonial empires, as it reproduces the Cold War distinction between "the first world" and "second world", as well as obscures important differences that pertain not only to political organization and administration, but also social ideology, aesthetic taste, and moral intention (Yurchak, 2006; see also Slezkine 1994). Merritt's suggestion that the Latvian national identity project is haunted by the Latvians' Soviet, that is, colonial past falls within the comparative framework criticized by Yurchak.

Such impetus to render the post-Soviet postcolonial vis-à-vis the equation of the Soviet state with British and French colonial empires seems to support Sharad Chari's and Katherine Verdery's (2009) observation that collapse of the Soviet Union and disintegration of the "second world" has not necessarily lead to a reconfiguration of the Cold War terrain of 
DRAFT - Please do not circulate without the author's permission

knowledge production. There is still an overwhelming presence of the "West and the Rest" or the "three worlds" approach in mainstream and critical scholarship. Instead, Chari and Verdery suggest that a conversation between the two "posts"-postcolonialism and postsocialism - could be generative on three accounts: critique of contemporary imperialism and neoliberalism; reworking of the Cold War geopolitics, including knowledge practices; and critique of state racisms, that is, of "institutional and biopolitical mechanisms, which differentiate populations into subgroups having varied access to means of life and death" (2009: 12). The suggested analytical trajectories are oriented towards a critique of the present structured by racialized hierarchies and epistemologies.

A move in this direction can be observed in more recent engagements with the relationship between postcolonialism and postsocialism which are concerned with the positioning of postsocialist and postcolonial states, subjects, and knowledge practices within the global hierarchies of power. For example, the Polish anthropologist Michał Buchowski (2004) has voiced an opinion that no recognized anthropological theory has ever come from Central Eastern Europe and suggested that Central Eastern European anthropology should be integrated into the Western economy of knowledge production thereby undoing the hierarchies that exist between Eastern ethnologists and Western anthropologists. ${ }^{\text {vi }}$ In a resonant argument, the Russian gender studies scholar Elena Gapova (2008) has suggested that debates about the colonial nature of the Soviet state in Russia are not so much interested in history as they are animated by postsocialist scholars' attempts to obtain recognition in Western academia. Gapova argues that the "appropriation of the postcolonial agenda" by Russian scholars is inspired by "the intellectual curtain" which prevents them from becoming players in the global intellectual field (2008). In Gapova's view, the postcolonial scholars' relationship with the West provides postsocialist intellectuals with a recognizable platform from which to problematize their voice in relation to Western academia. Zsuzsa Gille (2010), 
DRAFT - Please do not circulate without the author's permission

in turn, argues for a relational approach in making sense of the prevailing national(ist) discourses in Central Eastern Europe, specifically Hungary, through which right-wing politicians articulate political grievances and claims. Drawing on Stuart Hall, Gille writes that understanding the ways in which the Eastern European political terrain is constituted in a dialectical relationship with the West leads one to conclude that the national(ist) subject positions are comparable to first stages of postcolonial politics where "post" is primarily "anti," that is, an essentialist move necessary for becoming a political subject. The "anti" of the postsocialist "post," however, is not directed towards the socialist past, but rather towards the global present (2010: 22, see also Rogers, 2009; Kideckel, 2009).

However, even this excellent scholarship largely uses postcolonial theory to illuminate the power relations between postsocialist subjects and the West, thus arguably equating postsocialism with postcolonialism within the category of the Rest. For example, while Gille's relational approach moves beyond a bounded analysis of Hungarian nationalism by asking how this nationalism emerges in the context of Hungary's attempt to establish political agency in relation to the West, it constructs an equivalence between the postcolonial "anti" and the postsocialist "post" and thus does not explicitly consider what difference, if any, postsocialism introduces with regard to the struggle against the hegemony of the West. It's critical force, therefore, lies within the space of the postcolonial.

While some scholars imbue inquiry of postsocialism with critical force through its articulation with postcolonialism, others, such as Neil Lazarus, have accused "post-Soviet criticism" for reproduction of Eurocentrism by seeking "to install oneself at the very heart of "Europe"- as "core European"- by way of emphasizing not only one's modernity (despite one's belatedness on the scene, so to speak), but also, and however paradoxical this may sound, one's postcoloniality" (2012: 126). I read Lazarus as arguing that assuming a postcolonial positionality reproduces the centrality of a particular conception of Europe, since 
DRAFT - Please do not circulate without the author's permission

Lazarus criticizes postcolonial theory for reifying the idea of homogenous Europe and not recognizing internal differentiation within Europe. Lazarus seems to overlook the social fact that the category of Europe has an enormous discursive force even in conditions when there is no unified space called Europe. At the same time, one might agree with Lazarus that it is indeed worth investigating how Europe and its internal differentiations are articulated in particular historical conjunctures and especially in relation to postsocialist spaces and subjects. Deployment of postcolonial theory may indeed be of limited use here, as it does tend to invoke the dichotomy of the West and the Rest, thus the difference that a European postsocialist perspective might introduce gets subsumed in this dichotomy.

Within the juxtaposition between the West and the postcolony, the West gains its mastery by attempting to render the postcolonial subject knowable and governable, whereas the postcolonial subject always already exceeds this frame vis-à-vis her incommensurable difference (e. g. Chakrabarty, 2000). While not entirely outside the Western sphere of knowledge, the postcolonial subject nevertheless has access to a space of otherness, which can be a location of critical enunciations. European postsocialist spaces and subjects are not quite legible from within this framework, because they are neither one, nor the other. They are not quite the West, as it is continuously illustrated in both scholarly and public discourse. And they are also not quite the Rest, for, while they are subjected to similar techniques of government as postcolonial spaces and subjects, the critical space of radical otherness, so familiar from postcolonial contexts, seems elusive, if not entirely absent, in European postsocialism. As Madina Tlostanova and Walter Mignolo have pointed out with the help of a quotation from Victor Yerofeyev, "From Moscow I can go to Asia, if I want, or to Europe. It is clear where I am going to. It is not clear-where I am coming from...." (Tlostanova and Mignolo 2012: 36). 
DRAFT - Please do not circulate without the author's permission

I suggest that this discursive location is analytically generative precisely because elusive. Latvians are constituted as racialized and racializing subjects not only in relation to Soviet legacy, but also in relation to the broader framework of coloniality and its racializing hierarchies and epistemologies. Importantly, the specificity of the encounter between the Latvians' colonial aspirations and the Western traveller's interpretations of them cannot be accessed by resorting to a new metaspace of analysis. Coloniality as an analytical lens does not offer such a metaspace, but rather urges to consider specific historical articulations in relation to each other and in relation to the rationality of coloniality. Thus, the specificity of the encounter between the Latvians' colonial aspirations and their Western interpretations becomes visible in relation to other encounters between the Latvians' colonial aspirations and attempts to make sense of them. Let me illustrate with an example.

I met Abdi while I was working with the African Latvian Association, an organization that was initially established in 2005 as a support group for people of African descent residing in Latvia. The group was established in response to a racist anti-European Union political advertisement that used images of some of the group's founding members while misleading them to think that the advertisement would be part of a pro-European Union campaign with an emphasis on cultural diversity. Shortly after its establishment, the Association acquired public presence as some of its more active members spoke out against racism. Abdi, a member of the Association, was a Somali cinematographer who graduated from the All-Soviet State Cinematographic Institute in Moscow, ended up living in Latvia, and in 2007 accompanied a group of Latvian businessmen and adventure-seekers on a road trip from Morocco to South Africa which took them through Gambia, the location of Duke Jacob's briefly held colonial possessions. I first heard about the expedition during communications training for the Association members on how to better communicate their concerns to the public. As part of the first round of introductions, the participants were 
DRAFT - Please do not circulate without the author's permission

invited to introduce themselves, as well as to speak about the kind of problems they thought were important to address publicly. Abdi spoke about the expedition. He told about an incident that occurred during a dinner the expedition members had with their Gambian hosts. As an attempt to tell the hosts about the country he came from, Māris, one of the expedition members, asked the hosts whether they knew that Latvia once had colonies in Gambia. Abdi narrated this as an example of Māris' preoccupation with placing Latvians on the world map and his lack of awareness that the invocation of such a colonial relationship might seem strange, if not offensive, to his Gambian hosts. Later, when I asked Abdi to elaborate, he offered more reflections on the expedition and its racialized and racializing dynamics. He told me how at the end of the expedition he had told Māris about his observation that at the outset of the trip Māris had a racist way of seeing the world. Abdi told Māris that the way Māris took photos, the way he saw Africa, was racist. Māris would zoom his camera to exotic sceneries of racialized poverty and nature while ignoring scenes that looked too similar to what he was used to. Towards the end of the trip, the direction of Māris' lens had evidently slightly shifted, though Abdi did not explain how that came to be. Abdi was able to tell Māris about his observations, because he did not accuse Māris of being essentially racist, but rather pointed out how Māris participated in a racialized way of seeing the world. Abdi did not attribute this to the collective past of Latvians or to Māris' moral failure, but rather to the ways in which Māris' life world was shaped by the prevailing racialized hierarchies and epistemologies - first, in the form boasting about Latvia's colonies as a way to place Latvia on the world map and, second, when seeing Africa through the racialized logic of colonial modernity.

This examples illustrates how an encounter with a Somali cinematographer rather than a Western traveller opens different avenues for analysing the Latvians' colonial aspirations. It becomes possible to shift focus from Latvian postcolonial trauma to the broader framework 
DRAFT - Please do not circulate without the author's permission

of coloniality within which Latvians are both racialized and racializing subjects. If Abdi's reading of the situation opens analysis onto the coloniality of power which organizes relations between all involved, the Western traveller's reading removes the Western traveller as the object of reflection and concentrates attention to specific instances of Latvian history which can account for the Latvians' misguided colonial aspirations.

What baffles the Western traveller, but not the Somali cinematographer, is that Latvians do not identify with the West's self-proclaimed values of freedom, democracy, and human rights in relation to which the West measures the rest of the world, but rather with Western colonialism, which the West would rather write out of its progress-oriented historical trajectory. The Western traveller is baffled and even though he tries to contain the Latvians' colonial aspirations within the framework of national identity, it does not quite work. The Western traveller cannot answer how it is that colonial history is an especially conducive site for becoming a modern political and historical agent.

In the remainder of this article, I interrogate the conditions that lead Latvians to seek historical agency in colonial history, as well as the racialized dynamics that enable Latvians to identify with the glories of Europe's colonial history while distancing from its injuries. This dynamic is telling about the ways in which coloniality remains constitutive of political life in Europe, as well as about how postsocialist spaces and subjects become recruited in Europe's efforts to retain moral authority in the global arena.

\section{In search of historical presence}

In late 19th and early 20th century Latvian historians set out to write a Latvian history against the grain of the history of "the territory and the cities" written by the Baltic German elites (Plakans 1999). Baltic German historians wrote an ethnically or socially undifferentiated history of urban and territorial development, of trade routes, and of political regimes. Latvians did not appear in this historical narrative, because they were not agents of history, 
DRAFT - Please do not circulate without the author's permission

but rather, as the $19^{\text {th }}$ century Baltic German ethnographer Augusts Bīlenšteins has noted, “a labouring mass" (Grāvere n.d.). As a result of the concerted effort of Latvian historians to reinterpret the existing historical data and to locate new historical sources, new themes were introduced in Latvian historiography, such as legal regulation of serfdom and peasant rebellions (Plakans, 1999: 299). Given that Latvian intellectuals were pursuing this project in line with the Herderian understanding of universal humanity as accessible only through particular cultures, these efforts were placed in the frame of a struggle against cultural domination (Ījabs, 2010).

Historical work on the Duchy of Courland resonates with these attempts. The majority of the labour force of the Duchy consisted of Latvians recognized at that time as a linguistically marked class of indentured serfs (Merkelis, 2005). While Baltic German records depict Latvians as unskilled peasant labour, Latvian historians, such as Edgars Andersons, argue that Latvian serfs were also involved in craftsmanship and manufacturing (Andersons, 1970a). Moreover, Andersons suggests that Latvians participated in the Duke's colonial expeditions. Andersons, who wrote from exile in the United States, defended a doctoral dissertation at the University of Chicago in 1956 on the 17th century colonial exploits of the Duchy of Courland in Tobago and the Gambia. Like many other Latvians whose families left Latvia at the end of World War II to escape Soviet power, Andersons spent much of his personal and professional life furthering the goal of Latvian nation building from exile. In his book Tur plīvoja Kurzemes karogi (1970a), published by a Latvian publishing company in New York, Andersons analyses ship records of the Duchy's fleet that traversed the Atlantic participating in the triangle trade. Andersons describes the gruesome conditions under which the Duchy's colonial expeditions took place-shortages of food and water, conflicts with other colonial powers en route, rebellions of the ships` crews, foul weather, and disease. On numerous occasions Andersons suggests that historical records 
DRAFT - Please do not circulate without the author's permission

might contain traces of Latvian presence in these colonial expeditions. Describing the crew of the Di Mullen expedition which left Courland for the Gambia in September of 1652 on a ship called Patientia [Patience], Andersons writes: "The majority of crew members were Germans, Danes, Swedes, and, one should think, also some Latvians. Warkell might be Varkalis. Virwarr could be Visvars, quite a popular family name in Courland" (1970a: 77). Some pages later, when describing the hardships encountered by the crew, Andersons writes: "The following days were dark, with snow and rain. The storm was throwing the ship back and forth. Jākobs Pētersens Vārna (Waarn) died on February 25. Was he a Latvian? Let the linguists answer that" (1970: 90).

Andersons does not suggest that Tobago and Gambia were colonized by Latvians or that the Duchy's colonial pursuits should be claimed as Latvian national heritage, but rather that the Duke might have recruited Latvian serfs to man the ships and to settle the colonies. In doing so, Andersons tries to establish a Latvian presence in this colonial history, which has been denied to them by dominant historical narratives. Andersons writes against works such as that of Otto von Mattiesen (1940) - a historian of German heritage — which suggest that the colonization efforts were organized solely by Baltic Germans and that there were no Latvians in Tobago at all (Merritt, 2010: 497).

Andersons died in 1990, but until then he organized bi-annual commemorative gettogethers on the island of Tobago that still take place and are attended mostly by émigré Latvians from South and North America. These gatherings served to remind the Latvian diaspora living outside Soviet Latvia that even though Latvia's statehood was short livedLatvia became an independent state only in 1918 and lost independence in 1940, Latvians had a world historical presence long before that. It is here that Jānis, a Latvian living in California, met Professor Andersons and, as Jānis told me in Los Angeles in 2010, came up with his "crazy idea" to visit the former "Latvian colony in the Gambia." 
DRAFT - Please do not circulate without the author's permission

Jānis' visit was enabled by the flourishing of postcolonial heritage tourism that emerged in the United States following the publication of Alex Haley's book Roots in the 1970s and the production of a TV series with the same title. American travel agencies organized tours to a village in the Gambia that was allegedly the home of Kunta Kinte-Alex Haley's slave ancestor (Bellagamba, 2009). In 2004, Jānis went on such a roots tour to the Gambia along with about thirty African Americans who wanted to connect with their ancestry.

Jānis had learned much from Andersons, including his skill in reading the historical record and material evidence for traces of Latvian presence. That afternoon back in November 2010, Jānis told me about some paintings he saw in a museum in the Gambia, which depicted shocks of rye — a sight characteristic of the Latvian countryside. "Who could have painted those, and how did they get there?" Jānis asked suggestively, implying some Latvian connection. After all, Jānis had gone to the Gambia in search of his roots, as he later admitted to his travel companions to whom he had initially said that he was simply interested in history. Somewhat surprising his fellow travellers, when visiting the old fort on James Island in the Gambia, Jānis pulled out the flag of the Duchy—a black crab on a red background - which he had made before the trip. ${ }^{\text {vii }}$ He presented the flag to the Gambian Minister of Culture and Tourism saying that the flag of the Duchy deserves to fly on the fort alongside other colonial flags, including that of the contemporary Latvian state. ${ }^{\text {viii }}$

This was not the first time the flag of the Duchy had appeared on the island. About the same time that Jānis was on his tour, a film-crew from Latvia was visiting Gambia and filming material for what was to be a three-part documentary Riga-Banjul-Scarborough: Following the Footsteps of Latvian Dreams. The filmmakers-seasoned Latvian TV producer Pēteris and amateur American Latvian filmmaker Inga-wanted to make the film "to raise the self-confidence of Latvians" which, they thought, was seriously lacking. "If you 
DRAFT - Please do not circulate without the author's permission

don’t know why you are Latvian," said Pēteris in a conversation over dinner, "if you cannot fill that with positive content, then we are in big trouble." "The main message of the film," he continued, "is that we have a history, and that each nation needs its self-confidence." Similar to Harry Merritt, Pēteris suggested that Latvian self-confidence had been crushed by Soviet rule. It seriously needed reviving, and the glories of Duke Jacob seemed like a good place to start.

As the visual images shot from a boat pan across the coasts of the Gambia, the film's narration suggests that contemporary Latvians could find reason for self-confidence in the memory of their ancestors who sailed dangerous seas and constructed colonial forts. In another scene, the filmmakers Pēteris, Inga and their team likewise present the flag of the Duchy of Courland - a black crab on a red background - to their Gambian guides. The film shows Gambians raising the flag above the former colonial fort. "We need to learn the history of slavery," says the Gambian guide, "and that's why we need to learn the history of Courland." ${ }^{\text {ix }}$ In response, an ethnologist accompanying the film crew adds: "knowing history can make us take our place in history." Whereas the Gambian guide emphasizes that learning the history of Courland is necessary for learning about the "darker side" of modernity, the Latvian ethnologist emphasizes that learning the history of Courland is necessary for finding a place for Latvia in History.

In her essay on alternative universal history, Susan Buck-Morss shows that more often than not historical facts cannot be contained within the exclusionary conceptual frames of the nation and the state, yet hegemonic historical narratives continuously posit nations and states as primary agents of history (2009: 110). The history of the Duchy of Courland as written by Edgars Andersons and as lived by Jānis and Pēteris illustrates this tension. While all are trying to establish the presence of Latvians on the world historical stage, that is, to write the history of underdogs, they do so firmly within the discursive frame provided by the 
DRAFT - Please do not circulate without the author's permission

hegemony they wish to unsettle. If late $19^{\text {th }}$ and early $20^{\text {th }}$ century Latvian historians, not unlike scholars of subaltern studies (e. g. Guha, 1988), read between the lines of historical records in order to delineate alternate historical problem-spaces, Anderson's work reiterates hegemonic understandings of historical agency as primarily national by ignoring the wide variety of people on the Duke's ships and focusing on the link between the political and economic history of the Duchy and the presence of ethnic Latvians in it. Latvian serfs may or may not have been on the Duke's ships. Either way, there is no necessary connection between identifying a Latvian presence amidst the sailors and settlers and folding this presence into a narrative of national historical presence. The coloniality of power marking and mapping out the historical trajectory of the West and the Rest has likewise produced a particular historical imagination, one that privileges the bounded historical subject of the nation or the state. The framework of coloniality enables tracing how Latvians have historically attempted to become a people with history, that is, a people that are moving along the trajectory of civilization or world historical development by cultivating a national culture or struggling for national selfdetermination. ${ }^{\mathrm{x}}$ It also enables to show how this is a profoundly racialized process within which race as a marker of human difference becomes attached to temporal and developmental categories, which render Latvians as permanently belated newcomers to modern history and politics.

To conjure up imagination of a different historical space, Susan Buck-Morss (2009) draws on Peter Linebaugh and Mark Rediker's research where they analyse 17th and 18th century Atlantic slave trade from the perspective of the "dispossessed commoners, transported felons, indentured servants, religious radicals, pirates, urban labourers, soldiers, sailors, and African slaves,"- that is, the "motley crew" or the proletariat of the Atlantic (Linebaugh and Rediker, 2000: 4; see also Gilroy, 1993; Clifford, 1994). Linebaugh and Rediker argue that as much as the English and Dutch colonial rulers strove to impose order 
DRAFT - Please do not circulate without the author's permission

on their "global labour force," the "motley crew" of the Atlantic developed practices of cooperation that often lead to rebellions, strikes, mutinies, thus claiming their own specific historical agency (2000: 5). The authors aim to recover "the lost history of a multi-ethnic class that was essential to the rise of capitalism and the modern global economy" whose historical invisibility is the effect of the "violence of abstraction in the writing of history" which takes the nation-state as an unquestioned framework of analysis.

Linebaugh's and Redicker's work has also inspired Paul Gilroy (1993) in his quest for a "transnational counterhistory" to nationalist orientations that animate not only the history of modernity and but also the history of black resistance. Critical of the centrality of essentialist national identities in black resistance narratives, Gilroy emphasizes the slave ship and the mobile scene of the Atlantic as formative of black resistance to colonial displacement. As noted by James Clifford, the writing of such a transnational counterhistory is a politically and analytically ambitious, even a utopian project (Clifford, 1994: 205), yet it forcefully argues for a different vision of the historical space, one based on connections and solidarities formed between those subject to history's violent displacement.

In the context of the juxtaposition between the hegemonic historical space of European modernity and the subjugated historical agency of the Atlantic motley crew or black diaspora, the Latvian case is interesting to think with. In his historical writings, Edgars Andersons describes the multi-ethnic crews of the Duke's ships, the rebellions that broke out on the ships due to food and water shortages. He writes of the drunkards and criminals, of disease and hardship, which required that crewmembers form solidarities across linguistic and other boundaries. And yet, despite the violence that connected this "motley crew" and imbued it with agency that on occasion made the expeditions change course, Andersons uses his interpretive energies to conjure up and emphasize a Latvian national presence. In asserting this national historical presence and agency, Andersons and Latvian intellectuals 
DRAFT - Please do not circulate without the author's permission

and their publics do not extend the boundaries of the historical space, but join the European story of modernity within which colonial expansion and slave trade are constitutive, if obscured elements. ${ }^{\mathrm{xi}}$ Yet, as I argue in the next section, rather than embrace colonial injuries — such as slave trade - as a necessary downside to the colonial glories, Latvians identify with colonial glories while distancing from colonial injuries. This is not unique to Latvians. Other European nations engage in resonant projects of parsing out colonial glories from colonial injuries. What is noteworthy, however, is the ways in which Latvians achieve the simultaneous identification and distancing in relation to both European colonial powers and non-European colonial subjects. This dynamic is telling about how coloniality of power is reproduced in contemporary Europe and how postsocialist Europe is recruited in this project.

\section{Compartmentalization of colonial legacy in Europe}

In public and political discourse across Europe, colonialism is often reduced to the political and legal fact of colonial possessions. National publics whose states did not have direct colonial relationships in the past claim innocence with regard to colonialism, and by extension with racism, thus overlooking the various ways in which they too have participated in and benefited from coloniality (Gullestad, 2005; Purtschert, 2011). In recent reflections on the question, Patricia Purtschert analyses a statement allegedly made by a Swiss government official during the 2001 Durban ant-racism conference in South Africa that "Switzerland has nothing to do with slavery, slave trade, and colonialism“ (2011: 173). Since its utterance, the phrase has taken on a life of its own-it has been cited, re-cited, critiqued, and contested. While the phrase has outraged a narrow circle of activists, Purtschert suggests that it resonates with broad segments of the Swiss public who also believe that Switzerland has nothing to do with colonialism. Purtschert points out that by claiming innocence with regard 
DRAFT - Please do not circulate without the author's permission

to colonialism on the basis that Switzerland did not have colonies, the Swiss overlook the fact that Swiss companies traded with and profited from colonial regimes, circulated colonial images, used colonial rhetoric, and sold and marketed colonial goods (Purtschert, 2011: 122). In other words, the Swiss overlook how they too were constituted as modern subjects vis-àvis global coloniality. Since political glory and shame are attached to nation-states as primary historical and political agents, there seems to be no discursive repertoire for publicly reflecting on the formation of the Swiss as modern subjects within the racialized power relations of coloniality.

Norwegian debates about the use of the word neger analysed by Marianne Gullestad (2005) exhibit a similar dynamic. Gullestad illustrates how the Norwegian public maintains that Norwegians cannot possibly be racist, because they did not possess colonies and thus did not participate in the direct implementation of oppressive racial regimes. Similar to the Swiss, Norwegians cleanse their modernity from colonialism by arguing that they did not politically and legally participate in the European colonial project, thus overlooking how coloniality remains constitutive of Norwegians as modern political subjects. Kesha Fikes shows that even states that did have colonies engage in absolution from colonial guilt. As described by Fikes, the Portuguese public holds that Portuguese colonizers were not racists due to their affective relationships with colonial subjects, thus defining racism as "the colonizer's absence of human compassion toward differently raced others abroad“" (2009: 39; see also Stoler, 2002). In turn, as illustrated by Elizabeth Povinelli, the Australian nation-state, as a state that aspires to membership in the global community of liberal democracies, that is, the West, cleanses its liberal present from colonial past by positing colonial violence as accidental to the social and political system at the basis of the contemporary state rather than generated by it (2002: 7). In the context of the West's attempts to cleanse its present from colonialism, it now becomes possible to see why the Latvians' colonial aspirations should baffle and bemuse 
DRAFT - Please do not circulate without the author's permission

the Western traveller. However, the Latvians too engage in distancing from the dark side of coloniality/modernity, though their distancing tactic diverges from the ones described above.

Throughout the film made by Pēteris and Inga, an emphasis on the Duchy's colonial presence, such as raising the colonial flag on Jacob's Fort in the Gambia, intermingles with moments of solidarity with the once enslaved Gambians. The fact of slave trade in which Courlanders were involved is noted and condemned, yet Latvians as a people are cleansed from association with it through an emphasis on their own indentured status within the Duchy of Courland. ${ }^{\text {xi }}$ When I prompted Pēteris to reflect on how pride in colonial glory went together with involvement in slave trade, he responded as follows:

You have to separate two things here. One, there is the thing you speak of, that is, the slave trade. Two, there is the building of national self-confidence, even as the nation might actually be in demise. But there is another thing here: Latvians themselves were not free people. They were indentured serfs and between indentured servitude and slavery ... well, those are just different phases. Then there is the question to what extent they [slave traders] were Latvians and to what extent they were Germans.

Pēteris' response was typical of how many people I spoke with related to the fact that Duke Jacob was involved in slave trade. The distancing tactics described above, as well as the Latvians' ability to both identify with the colonial project and absolve themselves from the injuries associated with it, invites analysis of the ways in which colonialism is compartmentalized in Europe and how this compartmentalization reproduces coloniality. ${ }^{\text {xii }}$

The compartmentalization of colonialism into constitutive elements that could be separated from each other and the associated reduction of "bad colonialism" to the political 
DRAFT - Please do not circulate without the author's permission

and legal fact of having colonies or, within that, to oppressive and compassionless ways of relating to colonial subjects, has created the possibility to obscure other constitutive elements of colonial projects, such as exploration, trading, and traffic in racialized and exoticized images, that is, the racialized and racializing frames of intelligibility that continue to order the world. Ironically, it has created the conditions within which it becomes possible to glorify colonial history as an integral element of the history of European modernity, something that has been done not only by Latvians, but also by other ambiguously positioned Eastern Europeans. For example, historian Lenny A. Urena (2010) describes in her PhD thesis how 19th century Polish explorers wanted to compete with European scientific explorers. Since Poland was not a state at the time, they were ridiculed at home. Yet, they argued that in order to be part of European modernity, Poles did not have to have a nation-state that possessed colonies. Being part of European modernity meant participating in the European project of knowledge production through exploration, which was possible from within other political structures. ${ }^{\text {xiv }}$ Once in Africa, Polish explorers attempted to distinguish their pursuit of the higher good - that is, knowledge - from the pursuit of profit in which European colonial powers were engaged. This episode is interesting precisely because it illustrates that identification with the project of European modernity was profoundly colonial even in the absence of colonial possessions. It should not therefore come as a surprise-nor cause bafflement - that for many in Latvia being part of European history means partaking in the colonial project. And yet, it seems to generate precisely that-bafflement and bemusement. I suggest that bafflement and bemusement arise as a result of the unsettling effect of the Latvian colonial aspirations with regard to Europe's self-narrative.

The separation of the achievements of European modernity from its colonial injuries is crucial for maintaining the integrity of European social and political forms. Moreover, as brilliantly shown by Joseph Böröcz (2006) in an article on the Hungarian critique of domestic 
DRAFT - Please do not circulate without the author's permission

anti-Romani racism, Hungarian liberal intellectuals have on occasion been helpful in perpetuating France's superiority by using it as a reference point for critiquing backwardness at home - that is, by positing Western Europe, here represented by France, as the seat of "goodness" in relation to Eastern Europe, here represented by Hungary, as the Europe of "not yet" (Böröcz, 2006: 117; see also Chakrabarty, 2000; Coronil, 2011). Böröcz goes on to elaborate the Hungarian liberals" practices of "strategic forgetting" which cleanse France from its colonial history and posit it as the beacon of liberal goodness in Europe (2006: 118). Similar dynamics can be observed throughout Eastern Europe in the form of tolerance promotion projects and minority rights monitoring missions carried out by European institutions or with their support (Author, 2010; Author, n.d.)

Such carefully upheld distinctions, separations, and forgettings threaten to explode when the Western traveller encounters Latvians or other Eastern Europeans who, in order to become European, do not appeal to Europe's respect for human rights or tolerance, but rather glorify a colonial past that is not even in any straightforward sense theirs. The reaction ranges from bafflement, as in the case of Merritt, to ridicule, as I observed in a conference where I attended a panel on Polish colonial entanglements and fantasies. One of the papers dealt with early 20th century Polish claims to have partaken in the European history of colonization. The presenter exhibited an openly mocking attitude towards the claims she described. It seemed her presentation took the form of an exposé. She expected everyone in the audience to understand intuitively how ridiculous such claims were without careful reflection about what precisely was so ridiculous about them. The audience responded as expected-by chuckling in moments marked by the presenter with a change in the tone of voice.

Yet, neither the absurdity of colonial claims nor their ability to produce laughter or discomfort, are necessarily evident to those who make them. Most often than not, those Latvians who perform the historical appropriation of the Duchy's colonial pursuits do so 
DRAFT - Please do not circulate without the author's permission

without much awareness of the possible effects of their utterances in European public and political space. And it is precisely this - the affective relationship of Latvians to Europe's colonial history that seems to suggest to the Western traveller that, indeed, Latvians are not yet European. In the eyes of the Western traveller, they seem to lack the skill to correctly identify those elements of the European past, which Europe wants to strategically forget rather than proudly remember. Thus the Latvians' and other not-quite-Europeans' colonial aspirations become yet another site through which the Western traveller or scholar can assert moral superiority, as well as authority to affectively and discursively interpret the situationby bafflement, bemusement, laughter and thereafter by explanations that locate the source of the colonial aspirations in the national histories of the not-quite-Europeans.

\section{Bafflement as interruption?}

The project of writing Latvian history as a countermove to being overrun by history cannot but fail in the sense that it must take up the categories of European modernity in making a claim to historical presence. These were, in fact, the conditions within which Latvian history was construed as a history of a Latvian cultural community in the late 19th and early 20th centuries and subsequently as a history of the Latvian political community following 1918 (Ijjabs, 2010). And these are the conditions within which Latvian historians, intellectuals, and ordinary people assert Latvian historical presence vis-à-vis Duke Jacob's colonial expeditions. And yet, while articulated through the categories of European modernity, the Latvian colonial aspirations produce unsettlement. ${ }^{\mathrm{xv}}$

Latvian identification with the European colonial project cannot be completely appropriated and contained by dominant discourses. It is the bafflement and ridicule that identification with the European colonial project produces that serve as markers of the impossibility of containment. Enthusiastic references to the Gambia and Tobago in public 
DRAFT - Please do not circulate without the author's permission

spaces and discourses in Latvia baffle the Western scholar and traveller, because identification with Europe's colonial past is legible, yet unintelligible. ${ }^{\mathrm{xi}}$ On the one hand, Latvians speak a recognizable language of a national history. On the other hand, they earnestly articulate claims to a colonial past from which much of Europe wants to distance itself (e.g. Purtschert, 2011; Gullestad, 2005). Consequently, the Latvians' colonial aspirations bring into sharp focus the fact that colonial expansion, slavery, and racism are fundamentally constitutive of European modernity and that attempts to cordon them off from the political virtues of freedom, democracy, and human rights, which Europe claims as its contribution to humanity, ultimately fail.

The scene of bafflement whereby a Western traveller encounters Latvians striving to be colonial is a site for critical analysis of the coloniality of power in Europe. It not only enables one to show the ways in which coloniality remains constitutive of Europe, but also to trace the mechanisms through which coloniality is written out of European modernity. Postsocialist Eastern Europe plays a particularly central role here. On the one hand, postsocialist Eastern Europeans facilitate the erasure of coloniality from Western Europe's self-narrative by becoming objects of democratization projects, which entail monitoring and supervision of the "not-quite-European" East by the "always-already-there" West. On the other hand, postsocialist Eastern Europeans throw that project into disarray when in order to overcome their seemingly permanent "not-quite-European" position they strive to identify with colonialism, thus challenging the criteria of "goodness" in Western Europe's selfnarrative. Thus, in conditions when stating that the global present is structured by the coloniality of power is to nearly state the obvious, the anthropology of postsocialism enables a detailed analysis of the material and discursive practices, which reinvent and reproduce it. Importantly, this analysis shows that the source of bafflement lies not necessarily in the backward sensibilities of "not-quite-European" subjects, postsocialist or otherwise, but within 
DRAFT - Please do not circulate without the author's permission

the very European modes of racialized and racializing modes of government and knowledge production.

$* *$

In conditions when stating that the global present is structured by the coloniality of power is to nearly state the obvious, postsocialist Eastern Europe enables critical engagement with the coloniality of power without offering a promisory space of freedom where colonial legacy has finally been overcome. This, I contend, is the location of the analytical potential of postsocialism, one which works against the limits of both, Western social theory and its postcolonial critique.

\section{Acknowledgements}


DRAFT - Please do not circulate without the author's permission

\section{References}

Andersons, Edgars (1970a) Tur plīvoja Kurzemes karogi [There flew the flags of Courland]. New York: Grāmatu Draugs.

Andersons, Edgars (1970b) Senie Kurzemnieki Amerikā un Tobago kolonizācija [Ancient Couronians in America and Tobago]. Stockholm: Daugava.

Arenas, Ivan (2006) Oversight/site: Modernity and Its Rem(a)inders. In Modernism and Modernity in the Mediterranean World. Somigli, Luca and Domenico Pietropaolo, eds. Toronto: Legas. Pp. 131-150.

Bellagamba, Alice (2009) Back to the Land of Roots: African American Tourism and the Cultural Heritage of the River Gambia. Cahiers d'études africaines 193-4(1-2): 456-73.

Böröcz, Joseph (2006) Goodness is Elsewhere: The Rule of European Difference. Comparative Studies in Society and History 48 (1): 110-137.

Buchowski, Michał (2012) Intricate relations between Western anthropologists and Eastern ethnologists. Focaal: Journal of Global and Historical Anthropology 63(2012): 20-38.

Buchowski, Michał (2004) Hierarchies of Knowledge in Central Eastern European Anthropology. The Anthropology of East Europe Review, 22(2): 5-14.

Buck-Morss, Susan (2009) Hegel, Haiti, and Universal History. Pittsburgh: University of Pittsburgh Press. 
DRAFT - Please do not circulate without the author's permission

Chakrabarty, Dipesh (2000) Provincializing Europe: Postcolonial Thought and Historical Difference. Princeton: Princeton University Press.

Chakravarty, Paula and Denise Ferreira da Silva (2012) Accumulation, Dispossession, and Debt. American Quarterly, 64(3): 361-385.

Chari, Sharad and Katherine Verdery (2009) Thinking Between the Posts: Postcolonialism, Postsocialism, and Ethnography After the Cold War. Comparative Studies in Society and History 51(1): 6-34.

Chatterjee, Partha (2011) Reflecting on 30 Years after Subaltern Studies: Conversations with Prof. Profs. Gyanendra Pandey and Partha Chatterjee, interview conducted by Richard McGrail. Cultural Anthropology http://www.culanth.org/?q=node/469

Chatterjee, Partha (1986) Nationalist Thought and the Colonial World: A Derivative Discourse. London: Zed Books.

Chernetsky, Vitali (2003) Postcolonialism, Russia and Ukraine. Ulbandus. 7:32-62.

Clarkson, Andy (2003) Review of Roman Rosdolsky, Engels and the "NonHistoric" Peoples: The National Question in the Revolution of 1848. Critique, Glasgow, 1987, pp. 220. Web publication at: http://www.marxists.org/history/etol/revhist/backiss/vol3/no2/rosdolsk.html (Accessed March 2, 2012). 
DRAFT - Please do not circulate without the author's permission

Clifford, James (1994) Diaspora. Cultural Anthropology 9(3): 302-338.

Collier, Stephen, Alex Cooley, Bruce Grant, Harriet Muray, Marc Nichanian,

Gaytri Chakravorty Spivak and Alexander Etkind (2003) Empire, Union, Center, Satellite: A Questionnaire. Ulbandus 7:5-25.

Cooper, Frederick (2007) Provincializing France. In Stoler, Ann Laura, Carole McGranahan \& Peter C. Perdue (eds) Imperial Formations. Santa Fe: School for Advanced Research Press, pp. 341-378.

Coronil, Fernando (2011) "The Future in Question: History and Utopia in Latin America (1989-2010). In Calhoun, Craig and Georgi Derlugian (eds). Business as Usual: The Roots of the Global Financial Meltdown. New York: New York University Press and Social Science Research Council, pp. 231-264.

Brown, Wendy (2006) Regulating Aversion: Tolerance in the Age of Identity and Empire. Princeton: Princeton University Press.

Edgar, Adrienne Lynn (2004) Tribal Nation: The Making of Soviet Turkmenistan. Princeton: Princeton University Press.

Escobar, Arturo (2007) "Worlds and Knowledges Otherwise. The Latin American Coloniality/Modernity Research Program.” Cultural Studies 21(2/3): 179-210.

Fanon, Frantz (1967) Black Skin, White Masks. New York: Grove Press. 
DRAFT - Please do not circulate without the author's permission

Ferreira da Silva, Denise (2005) A Tale of Two Cities: Saigon, Fallujah, and the Ethical Boundaries of Empire. Amerasia, 31(2): 121-134.

Fikes, Kesha (2009) Managing African Portugal: The Citizen-Migrant Distinction. Duke: Durham University Press.

Gapova, Elena (2008) Roundtable "Sub Altera Specie": A View at Postcolonial Paradigm from Inside Russian/Soviet History. Ab Imperio: Studies of New Imperial History and Nationalism in the Post-Soviet Space 2008(2): 88-89.

Gille, Zsuzsa (2010) Is there a Global Postsocialist Condition? Global Society 24(1): 9-30.

Gilroy, Paul (1993) The Black Atlantic: Modernity and Double Consciousness. Boston: Harvard University Press.

Grāvere, Rita (n.d.) Antropologijas vēsture Latvijā [History of Anthropology in Latvia]. Unpublished manuscript.

Guha, Ranajit (1988) The Prose of Counterinsurgency. In Ranajit Guha, Gyatri Chakravorty Spivak and Edward Said (eds) Selected Subaltern Studies. Oxford University Press.

Gullestad, Marianne (2005) Normalising Racial Boundaries: The Norwegian Dispute about the Word Neger. Social Anthropology 13(1): 27-46. 
DRAFT - Please do not circulate without the author's permission

Hann, Chris (2012) Faltering Dialogue? For a Doubly Rooted Cosmopolitan Anthropology. Focaal: Journal of Global and Historical Anthropology 63(2012): 39-50.

Hann, Chris (2005) Correspondence: Reply to Michal Buchowski. Anthropology of East Europe Review 23(1): 194-197.

Hirsch, Francine (2005) Empire of Nations: Ethnographic Knowledge and the Making of the Soviet Union. Ithaca: Cornell University Press.

Ijabs, Ivars (2010) Strange Baltic Liberalism: Paul Schiemann's Political Thought Revisited. Journal of Baltic Studies 40(4): 495-515.

Jakovḷeva, Mārīte (2010) Veltījums Kurzemes literatūras un mākslas biedrībai [Dedication to the Kurzeme Association of Literature and Art]. Latvijas Arhīvi, 2010(2): 300-302.

Juškevičs, Jānis (1931) Hercoga Jēkaba laikmets Kurzemēe [The Age of Duke Jacob in Courland]. Rīga: Valsts papīru spiestuve.

Kelertas, Violeta (2006) Introduction: Baltic Postcolonialism and Its Critics. In Keletertas, Vioeleta (ed) Baltic Postcolonialism. Amsterdam: Rodopi, pp. 1-9.

Khalid, Adeeb (2007) The Soviet Union as an Imperial Formation: A View from Central Asia. In Stoler, Ann Laura, Carole McGranahan \& Peter C. Perdue (eds) Imperial Formations. Santa Fe: School for Advanced Research Press, pp. 113-140. 
DRAFT - Please do not circulate without the author's permission

Kideckel, David (2009) Citizenship Discourse, Globalization, and Protest: A PostsocialistPostcolonial Comparison. Anthropology of East Europe Review 27(2): 117-133.

Klumbyte, Neringa (2011) Europe and Its Fragments: Europeanization, Nationalism, and the Geopolitics of Provinciality in Lithuania. Slavic Review 70(4):

Lazarus, Neil. 2010. Spectres Haunting: Postcommunism and postcolonialism. Journal of Postcolonial Writing 48(2): 117-129.

Linebaugh, Peter \& Mark Rediker (2000) The Many-Headed Hydra: Sailors, Slaves, and Commoners, and the Hidden History of the Revolutionary Atlantic. Boston: Beacon Press.

Mattiesen, Otto 1940 Die Kolonial- und Überseepolitik der kurländischen Herzöge im 17. und 18. Jahrhundert $\left\{\right.$ Duke Jakob's colonial politics in the $17^{\text {th }}$ and $19^{\text {th }}$ centuries]. Stuttgart.

Mehta, Uday (1999) Liberalism and Empire: A Study in the Nineteenth Century British Liberal Thought. Chicago: Chicago University Press.

Merķelis, Garlībs (2005) [1797] Latvieši [Latvians]. Rīga: Zvaigzne ABC.

Merritt, Harry C. (2010) The Colony of the Colonized: The Duchy of Courland's Tobago colony and contemporary Latvian national identity. Nationalities Papers 38(4): 491-508.

Mignolo, Walter and Madina Tlostanova. 2007. The Logic of Colonality and the Limits of Postcoloniality. The Postcolonial and the Global: Connections, Conflicts, Complicities, 
DRAFT - Please do not circulate without the author's permission

Revathy Krishnaswamy and John C. Hawley (eds). Minneapolis: University of Minnesota Press. Pp. 109-123.

Mirbahs, Otto (2010) [1899] Vēstules par Kurzemes hercogu Jēkabu [Letters about Duke Jacob of Courland]. Elza Stērste, transl. Jelgava: Allunans.

Mitchell, Timothy (1991) Colonising Egypt. Berkeley: University of California Press.

Morris, Rosalind C. (2010) Introduction. In Rosalind C. Morris (ed) Can the Subaltern Speak? In Reflections on the History of an Idea. New York: Columbia University Press, pp. $1-20$.

Northrop, Douglas (2004) Veiled Empire: Gender and Power in Stalinist Central Asia. Ithaca: Cornell University Press.

Plakans, Andrejs (1999) Looking Backward: The eighteenth and nineteenth centuries in interwar Latvian historiography. Journal of Baltic Studies 30(4): 293-306.

Prakash, Gyan (2000) The Impossibility of Subaltern History. Nepantla: Views From South 1(2): $287-294$.

Purtschert, Patricia (2011) Chewing on Post-colonial Switzerland. Redigesting what has not yet been swallowed, Part II. In Thal, Andrea (ed) Chewing the Scenery 2nd Edition. Zurich, pp. 95-100, pp.121-126, and pp. 149-154. 
DRAFT - Please do not circulate without the author's permission

Quijano, Anibal. 2000. Coloniality of Power, Eurocentrism and Latin America. Nepantla: Views from South 1(3): 533-580.

Rabinow, Paul (1995) French Modern: Norms and Forms of the Social Environment. Chicago: University of Chicago Press.

Račevskis, Kārlis (2002) Towards a Postcolonial Perspective on the Baltic States. Journal of Baltic Studies 23(1).

Rogers, Douglas (2010) Postsocialisms Unbound. Slavic Review 69(1): 1-15.

Slezkine, Yuri (1994) Artic Mirrors: Russia and the Small Peoples of the North. Ithaca: Cornell University Press.

Stoler, Ann Laura (2002) Carnal Knowledge and Imperial Power: Race and the Intimate in Colonial Rule. Berkeley: University of California Press.

Strods, Heinrihs (1987) Kurzemes kroņa zemes un zemnieki, 1795-1861 [Lands and peasants of Courland imperial territories, 1795-1861]. Rīga: Zinātne.

Ticktin, Miriam, Paolo Bachetta \& Ruth Marshall (2007) "A Transnational Conversation on French Colonialism, Violence, Immigration, and Sovereignty." The Scholar \& Feminist Conference XXXII, "Fashioning Citizenship: Gender and Immigration," held on March 24, 2007 at Barnard College. Available on: http://sfonline.barnard.edu/immigration/conversation_01.htm 
DRAFT - Please do not circulate without the author's permission

Tlostanova, Madina. 2012. Postsocialist $\neq$ postcolonial? On post-Soviet imaginary and global coloniality. Journal of Postcolonial Writing 48(2): 130-142.

Tlostanova, Madina V. and Walter Mignolo. 2012. Learning to Unlearn: Decolonial Reflections from Eurasia and the Americas. Columbus: Ohio University Press.

Urena, Lenny A. (2010) The Stakes of Empire: Colonial Fantasies, Civilizing Agendas, and Biopolitics in the Prussian-Polish Provinces (1840-1914). Ph.D. Dissertation. Ann Arbor: University of Michigan.

Verdery, Katherine (1994) Beyond the Nation in Eastern Europe. Social Text 38 (Spring): 119.

Wolf, Eric R. (1997) [1982] Europe and the People Without History. Berkeley: University of California Press.

Yurchak, Alexei (2006) Everything Was Forever Until It Was No More: The Last Soviet Generation. Princeton: Princeton University Press.

Zalsters, Artūrs Eižens (2002) Hercoga Jēkaba burinieki [The ships of Duke Jacob]. Rīga: Izdevniecība AGB.

\footnotetext{
${ }^{\text {i }}$ Personal communication.
} 
DRAFT - Please do not circulate without the author's permission

ii Anthony D. Smith ethno-symbolist theory argues that "though nations are themselves essentially modern creations, they draw upon the pre-existing history of a demographic group" (Merritt, 2010: 501). Smith outlines three approaches for doing so: recurrence, continuity, and appropriation. Merritt argues that the first two-recurrence and continuityare not applicable to Latvia, because Latvia, compared to Lithuania and other nations, has been a sovereign power for a very short period of time, and that therefore appropriation is the most appropriate scenario is appropriation, which, as Smith argues, reflects the tendency "of later generations, especially of nationalists, to rediscover, authenticate, and appropriate aspects of what they assume is 'their' ethnic past" (in Merritt, 2010: 501).

iii I am proposing therefore a relational rather than comparative analysis. Comparative analysis tends to carve out units of comparison without critical consideration of how these units became imaginable as separate entities in the first place. As argued by Madina Tlostanova and Walter Mignolo, "we are not "comparing" Central Asia and Caucusus, on the one hand, with South America and the Caribbean, on the other, but rather analyzing the underlying colonial matrix of power maintaining the illustion that these "areas" are far apart from each other (and they are, as far as local histories are concerned), while in fact they are linked ot the Western hegemony by the logic of coloniality" (2012: 2).

iv In a conversation held at Barnard College, Miriam Ticktin, Paola Bachetta and Ruth Marshall began their conversation about French colonialism, immigration and violence by discussing President Sarkozy’s 2007 address to African youth at the University of Anta Diop in Senegal where, according to the conversation participants, "he was recapitulating Hegel's ideas about Africa, suggesting that there is no historical time in Africa, that Africans still measure time through nature and that they need to be brought into history with a capital H" (2007: 1). I thank the University of California, Irvine Humanities Research Institute's 
DRAFT - Please do not circulate without the author's permission

Residential Research Group "Imperial Legacies, Postsocialist Contexts", especially Fatima El-Tayeb, for bringing the transcript of this conversation to our collective attention.

${ }^{v}$ In addition to the relational analytical approach I deploy this article, my article draws on analysis of ethnographic data, that is, participant observation and interviews across a variety of settings in which I encountered references to the Duchy of Courland in the course of my fieldwork on tolerance promotion projects in Latvia. For example, I participated in numerous events organized by the African Latvian Association, as well as interviewed Latvian intellectuals, historians, and individuals who had travelled to the Gambia in search of Latvian historical heritage. Ethnographic analysis was supplemented by analysis of secondary textshistorical writings, media articles, and scholarly literature. The object of analysis, as described in the text, is the encounter between discursively and materially articulated colonial aspirations of Latvians and their interpretations.

vi See Hann 2005 for a response. See also Buchowski, 2012 and Hann, 2012.

vii Courlanders had named the island St. Andrew's Island. The Brits later renamed it James Island.

viii Jānis said that the Latvian flag was already there, but I have not been able to confirm.

ix It should be noted here that while the Gambian political rhetoric emphasizes suffering inflicted by European slave-trade, it completely overlooks the issue of internal slavery which continued in the Gambia well after the Brits abolished slavery in the early 19th century (Bellagamba 2005).

x In 1849, Friederich Engels called Austrian Slavs a "people without history", as they had not joined the German revolutionaries in 1848, but sided with their landlords (in Clarkson 2003). In the Latvian context, Ivars Ijabs (2010) has shown how the respected Baltic German politician Paul Schiemann of the 1920s Latvia subscribed to the Herderian idea of the cultural nation as the only site for the realization of a universal humanity. For that purpose, all 
DRAFT - Please do not circulate without the author's permission

cultural communities had to strive for maturity in accordance with the path taken by the more civilized cultural communities such as that of Germans. Schiemann embraced a cultural liberalism of sorts where everyone was equal, but not everyone was mature enough to take full advantage of inhabiting humanity in the form of a cultural community. The ambiguous ethnic-class formation that was Latvians in the 19th century took up this version of universal humanism and labored to cultivate a Latvian cultural community in accordance with the German model.

xi As Gyan Prakash has argued with regard to codification of Hinduism as a religion in postcolonial India, Western dominance was imperative for constituting Hinduism as a national religion (2000: 289-290). See also Chatterjee 1986.

xii The historical aspects of indentured servitude, as well as the relations between Latvian serfs and their Baltic German owners are described in Strods 1987, as well as in Merķelis 2005 [1797].

xiii Describing a resonant dynamic, Josep Böröcz invokes Johannes Fabian's notion of the “denial of connectedness" (Böröcz 2006: 126).

xiv Both, the Polish and Latvian cases illustrate that the formation of cultural nations in Eastern Europe did not depend on political structures supporting them. See Verdery 1994 on the specificity of nations and nationalism in Eastern Europe.

${ }^{x v}$ Gyan Prakash has argued that the impossibility of "the history of the subaltern as a fullblooded subject-agent" does not mean that subaltern histories cannot be written (2000: 287). Subaltern histories do not require that the subaltern's position be entirely outside power. Rather, "subaltern knowledges and subjects register their presence by acting upon the dominant discourse, by forcing it into contradictions, by making it speak in tongues" (Prakash, 2000: 293). Prakash defines subalternity as "an abstraction used in order to identify the intractability that surfaces inside the dominant system - it signifies that which the 
DRAFT - Please do not circulate without the author's permission

dominant discourse cannot appropriate completely, and otherness that resists containment" (2000: 288). Thus, instead of thinking of subalternity as a category attached to concrete historical communities, Prakash thinks of subalternity as a relationally produced moment of unsettlement.

${ }^{x v i}$ I borrow the distinction between legibility and intelligibility from Anita Starosta who uses this distinction as an analytical took to engage with Eastern Europe in her work. Starosta explained this distinction in a session of the University of California Humanities Research Institute's Residential Research Group "Imperial Legacies, Postsocialist Contexts” that took place in the fall of 2012. See also Morris 2010 on subalternity and legibility, as well as Chatterjee 2011. See also Morris 2010 on subalternity and legibility, as well as Chatterjee 2011. 